\title{
Ser en relación y conocimiento de sí y en San Agustín y en Plotino
}

\author{
Claudio Pierantoni \\ UNIVERSIDAD DE CHILE \\ claudiopierantoni@yahoo.com
}

Resumen: Este artículo revisa los conceptos de ser en relación y de autoconocimiento en la Enéada V de Plotino y en la segunda parte De Trinitate de Agustín de Hipona. Muestra como en ambos autores el ser se auto-conoce como intrínsecamente relacional y dinámico, inserto en un proceso de continua conversión. En ambos, el conocerse del hombre en sus relaciones intra-psíquicas equivale a conocerse fundamentalmente en sus relaciones con la Divinidad. En el neoplatónico la relación del hombre con Dios termina confundiéndose con las relaciones entre las hipóstasis divinas. En el análisis agustiniano, las relaciones trinitarias, que el hombre descubre en su esencia interior, son espejo e imagen creada, netamente distinta de la Esencia Divina, aun cuando tales relaciones no operan sin la necesaria relación vertical con la Trinidad divina. Agustín lleva así a su primera sistematización el pilar fundamental que sostiene al mismo tiempo la Teología natural y la Antropología filosófica cristiana.

Palabras clave: Ser-en-relación, autoconocimiento, conversión, Plotino, neoplatonismo, San Agustín, filosofía cristiana, teología natural, antropología filosófica.

Abstract: This paper compares the concepts being-in-relation and self-knowledge in Plotinus' V Ennead and in the second part of St. Augustine's De Trinitate. It shows how in both authors being knows itself as intrinsically relational and dynamic, inserted in a process of continual conversion. In both, man's self-knowledge in his intra-psychical relations tantamounts to knowing himself in his relations with God. However, in the neoplatonic, man's relation to God ends up identified with the relations among the Divine hypostasis. In Augustine the trinitarian relations, man discovers in his interior essence, are a created mirror and image, sharply distinct from the Divine Essence, although they don't operate without the necessary vertical relation with the Divine Trinity. Augustine brings to its first sistematization the fundamental pillar that holds together Christian Natural Theology and Philosophical Anthropology.

Key words: Being-in-relation, self-knowledge, conversion, Plotinus, neoplatonism, St. Augustine, christian philosophy, natural theology, philosophical anthropology. 


\section{INTRODUCCIÓN}

Desde antiguo, el dicho del santuario del Apolo délfico "Conócete a ti mismo" (gnóthi seautón) ${ }^{1}$ ha estimulado la investigación filosófica en Grecia. Muy probablemente, su sentido originario incluye una exhortación moral al ser humano a no creerse más de lo que es en realidad, en otras palabras, a no presumir ponerse en el nivel de los dioses ${ }^{2}$. Este mismo sentido retoma Sócrates, interpretando el responso del oráculo, según el cual "Sócrates es el más sabio de todos los hombres"3. Sócrates, como es sabido, emprende una investigación entre los hombres considerados más sabios, para averiguar si el oráculo del dios era efectivamente verídico, y encuentra que todos presumen saber más de lo que saben; y en esto mismo él se encuentra más sabio porque, "lo que no sabe, tampoco cree saberlo" ${ }^{\prime}$. Pero es notable que Sócrates, más allá de su caso personal, pone el acento en el sentido más universal del dicho profético:

"A lo que parece, ciudadanos, es el dios, en realidad, el que es sabio, y esto quiere significar en su oráculo, que la sabiduría humana vale muy poco, por no decir nada, y parece que llamando a Sócrates 'sabio', ha utilizado mi nombre meramente como ejemplo, como si dijera: El más sabio entre vosotros, o hombre, es aquel que, como Sócrates, ha reconocido en verdad que, en cuanto a sabiduría, no vale nada"s.

Sócrates concluye diciendo que su servicio al dios consiste en seguir interrogando a los hombres para demostrar que no hay ningún sabio entre ellos, y así -al precio de tener muchos enemigos y vivir en la pobreza- darle la razón al oráculo divino.

Platón, más adelante, llevará esta experiencia socrática, de por sí muy significativa, a un mayor nivel de profundización en una famosa página del Alcibiades, que no sin razón pasará a ser durante siglos uno de los textos fundamentales de la enseñanza filosófica en la Academia.

1 Transmitido entre las sentencias de los Siete Sabios: cf. Diels-Kranz, Die Fragmente der Vorsocratiker, ( ${ }^{6} 1960$, vol. I,10) 63, 1. 25.

2 Una amplia historia del precepto délfico y su meditación en el mundo antiguo y medieval ha sido ofrecida por Pierre Courcelle, Connais-toi toi-même de Socrate a Saint Bernard (Paris, Études Augustiniennes, Tome I, 1974, Tome II, 1975).

3 Platón, Apología de Sócrates 21a (Ed. Duke-Hicken-Nicoll-Robinson-Strachan, Oxford 1995). Las traducciones presentadas son mías.

4 Platón, Apología 21d.

5 Platón, Apología 23 ab. 
En este texto, verdaderamente extraordinario, se plantea por primera vez en el pensamiento occidental la paradoja, el enigma, de lo que significa el autoconocimiento, el "mirarse a sí mismo" ${ }^{6}$. En efecto, cuando se trata del ojo físico, es claro que este no puede directamente mirarse a sí mismo. Si quiere mirarse, debe dirigirse a un artefacto particular, que llamamos espejo. Sin embargo, además del recurso artificial, también existe un recurso natural, un espejo humano, por decirlo así: y esto consiste en mirar a la pupila de otra persona, donde vemos reflejada nuestra imagen. La pupila, precisamente, es la parte más noble del ojo, donde reside la virtud de la vista. Ahora la pregunta es: cuando se trate de la mirada interior, la del alma, ¿cuál será el espejo invisible en el cual ella pueda reflejarse? Por analogía con la vista física, Platón concluye que:

"también el alma, si se quiere conocer a sí misma, tiene que mirar a otra alma, y especialmente a aquella parte de ella donde reside la virtud propia del alma, la sabiduría, o a alguna otra cosa a la que esta parte pueda resultar parecida"7.

Ahora bien, la parte mejor del alma es aquella donde reside el conocer

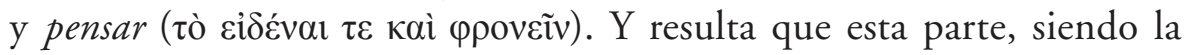
mejor, es la que más se parece al dios: "mirándola a ella, y conociendo también todo lo divino, el dios y el pensamiento, de este modo podría tener el más grande conocimiento de sí misma”.

El dios es, naturalmente, un espejo aún más puro y luminoso que la parte mejor de nuestra alma. Resume Platón: "Por lo tanto, mirando al dios, y, entre las cosas humanas, a la virtud del alma, nos serviremos del espejo más bello, y así podremos ver y conocernos a nosotros mismos lo más posible" 9 .

6 Sobre este texto y su relación con el neoplatonismo pueden verse las penetrantes reflexiones de Werner Beierwaltes, Selbsterkenntnis und Erfahrung der Einheit (Klostermann, Frankfurt am Main 1991).

7 Platón, Alcibiades, 133b, 7-10 (Ed. Burnet, Oxford ${ }^{18} 1988$ ).

8 Platón, Alcib., 133c, 4-6.

9 Platón, Alcib., 133c, 13-16. Algunos críticos han revocado en duda la autenticidad de estas últimas líneas del texto, basándose en el hecho que ellas faltan en los principales manuscritos y solo aparecen en un texto de Eusebio de Cesarea. Por lo tanto, las han sospechado de ser una interpolación neoplatónica o incluso cristiana (cf. A. Carlini, Studi sul testo della quarta tetralogia platonica, Studi italiani di filología classica, n.s. 34, 2, 355-358). Nosotros seguimos a W. BeIERWALTES (Autoconoscenza..., 50, nota 9), y R. WIGGERS (Philologische Wochenschrift, 52 1931, 
Esta página, como decíamos, quedará como el punto de partida fundamental de la enseñanza filosófica neoplatónica, que en último término, podría definirse como la respuesta más acabada y sistemática, en el mundo helénico, al desafío que planteaba desde antiguo el oráculo délfico: podría decirse que la esencia misma la filosofía neoplatónica es la sistematización del proceso de autoconocimiento, como clave de la cosmología, de la gnoseología y de la teología.

\section{SER EN RELACIÓN Y CONOCIMIENTO DE SÍ EN LA ENÉADA $V$ DE PLOTINO}

En el primer tratado de la Enéada $V$, Plotino plantea precisamente la necesidad que tiene el Alma de conocerse en su verdadero valor, y apreciarse convenientemente, para poder alejarse de los bienes inferiores y emprender su camino hacia Dios. Precisa que, antes de mostrar la bajeza de los bienes materiales, es necesario "hacer memoria al alma de cuál estirpe ella sea, de cuál nobleza, pues tal discurso, cuando sea claro, clarifica también el otro"10.

El Alma debe por tanto, en primer lugar, reflexionar que ella misma es "quien hizo vivientes a todos los seres, inspirándoles la vida"11.

Por este motivo, el alma sabe que tiene mayor valor que las cosas que se generan y se corrompen: ella, citando a Platón, "existe siempre, porque no puede dejarse a sí misma" ${ }^{12}$.

Siendo ella el principio vital, no puede morir: al contrario, es ella misma que, junto con animar al cosmos, le transmite el ser y la misma inmortalidad, naturalmente en su nivel, que es del ser en devenir: sin embargo, antes de ser animado, el mundo no era una nada absoluta, sino: "un cuerpo muerto, tierra y agua, tiniebla de materia informe, no-ser, del que hasta los dioses tienen horror"13. Se trata por tanto de no-ser en sentido relativo, por comparación con el ser ordenado y animado.

700-703), quienes han mostrado que el pasaje resulta perfectamente coherente son las sucesivas referencias que se hacen a este concepto (cf. Alcib. 134d 5).

10 Plotino, Enéada V, 1, 1, 28 (ed. Paul Henry-Hans Rudolf Schwyzer, Editio Minor, Oxford, 1964-1982).

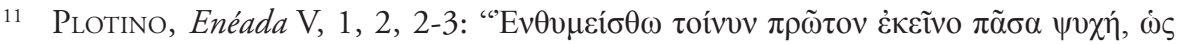

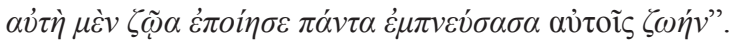

12 Platón, Fedro 245 c8.

13 Plotino, Enéada V, 1, 2, 25-26. 
El alma, también, posee una unidad que no se divide por las diferentes partes del cosmos que anima. Ella anima, además del mundo terrenal, el Sol y los Astros, que ciertamente son divinidades. El Alma misma, pues, "siendo causa de la divinidad para los dioses es un dios más antiguo que ellos"14.

Plotino concluye: "si lo que te asombra en otro es el alma, asómbrate de ti mismo" 15 .

Este descubrimiento asombroso del Alma, ciertamente ha inspirado las reflexiones agustinianas sobre la memoria en el Libro $\mathrm{X}$ de las Confesiones.

Habiendo llegado a este punto y habiendo tomado una primera conciencia de su verdadera naturaleza, el Alma está lista para el ascenso al grado superior y más divino, el de la Inteligencia. Esta es una realidad que está "más arriba" y, sin embargo se halla "en la cercanía”, pues el Alma viene de ella y es imagen de ella. Precisamente por eso, el Alma es intelectiva, pues viene de la Inteligencia, que, respecto de ella, es "como un Padre que se dedica a criar al hijo, que ha generado menos perfecto que él mismo"16. Por tal motivo, los actos más propios del Alma intelectiva son los que se dirigen a la Inteligencia y son diferentes de los que se dirigen "hacia abajo", para su actividad en el mundo sensible.

La naturaleza superior de la Inteligencia se manifiesta en el hecho que ella contiene en sí:

"[...] el modelo de este mundo y el ser que es más verdadero, [...] todos los seres inteligibles y eternos que están allí en la forma de conocimiento y de vida que les es propia, y la Inteligencia purísima que los dirige y la Sabiduría infinita" ${ }^{17}$.

Plotino insiste sobre todo en el carácter perfecto y eterno de la Inteligencia: ella "no busca la Verdad, porque la posee". En ella, el pensar y el

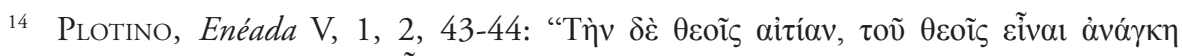

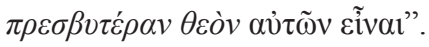

15 Plotino, Enéada V, 1, 2, 50.

16 Plotino, Enéada V, 1, 3, 15: “O

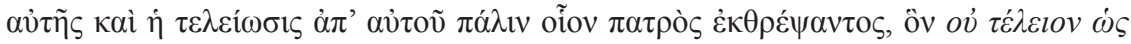

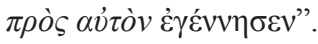

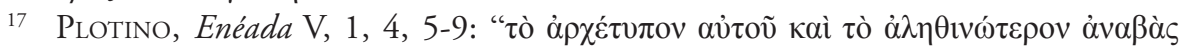

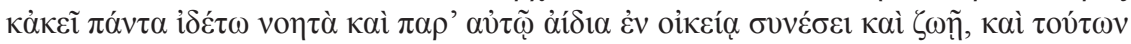

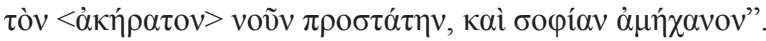


ser se identifican perfectamente, como lo expresa en la siguiente frase con extraordinaria densidad:

"Es Inteligencia y Ser, y el todo es toda la Inteligencia y todo el Ser, la Inteligencia según el pensamiento dando subsistencia al Ser, y el Ser, mediante su ser pensado, dando a la Inteligencia el pensar y el Ser"18.

Esta expresión -podría decirse- inserta en un preciso lugar metafísico la famosa sentencia de Parménides: "Lo mismo es el pensar y aquello por lo cual el pensamiento es, pues sin el ser en el cual se expresa, no encontrarás el pensar"19.

En la Inteligencia se encuentran, en la cumbre de los Inteligibles, los Principios Supremos: el Ser, la Diferencia, la Identidad, el Movimiento y la Quietud. A pesar de su perfección y unidad, sin embargo, se encuentra en ella todavía la multiplicidad. Por lo cual, ella reenvía a una hypóstasis aun superior, perfectamente Una y Simple, que la ha generado y por lo tanto es anterior al Ser y causa de él.

El Uno es causa en primer lugar de la Díada, la cual es de por sí indeterminada (aóriston), pero encuentra en el mismo Uno su determinación y así en base a la polaridad entre el Uno y la Díada indeterminada, que forma como el sustrato (hypokéimenon) o la materia inteligible, se genera el Ser, que coincide con el Mundo inteligible (kosmos noetós) o Inteligencia ${ }^{20}$.

Tal como la esencia profunda del Alma consiste en su contemplación de la Inteligencia, así la esencia íntima de la Inteligencia consiste en la contemplación del Uno. Por lo tanto, el ascenso del Alma a la Inteligencia debe finalmente trascender lo puramente intelectual y llegar a una ascensión supra-racional o mística: "Hablen de ello, los que han llamado a Dios en su ayuda, no con palabras, sino con el Alma extendida en una invocación dirigida a Él, y así nos estará concedido invocarlo solos al Solo"21.

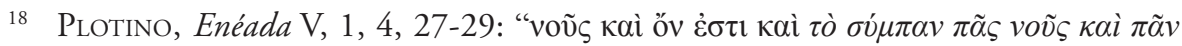

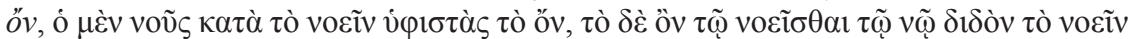

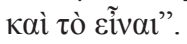

19 Parménides, Fragm. 22B8, ed. Reale, I Presocratici (Milano, 2006) pág. 53.

20 La polaridad entre el Uno y la Díada se remonta a las doctrinas no escritas de Platón. Sobre esta problemática, el necesario punto de referencia es el extenso análisis de Giovanni Reale, Per una nuova interpretazione di Platone (Milano ${ }^{21} 2003$ ), 497-593.

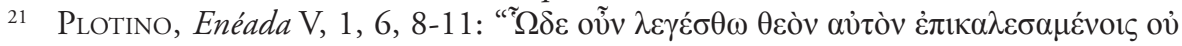

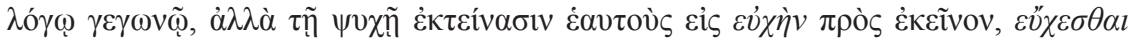


Sin embargo, a pesar de la alusión a la invocación de la ayuda de Dios, no parece darse, en esta mística, algo que podríamos llamar un diálogo con Dios, ni mucho menos una ayuda de carácter personal, voluntario, de parte de Dios. En efecto, el aspecto en que Plotino más insiste en este contexto, es que la absoluta inmovilidad de Dios incluye una absoluta ausencia de voluntad en Él, así como también una ausencia de conocimiento, como precisará más adelante: ambas cosas, en efecto, le parecen a Plotino entrar en contradicción insanable con la perfecta unidad del $\mathrm{Uno}^{22}$. Pues, aun cuando su conocimiento y su amor lo dirigiera rigurosamente a sí mismo, único objeto que sería digno, ambos conceptos involucrarían una dualidad sujeto-objeto que para Plotino es inaplicable al absoluto Uno.

En este contexto metafísico general es posible ahora comprender la doctrina plotiniana del conocimiento de sí, que se expresa en Enéadas V,3.

El itinerario del alma, argumenta Plotino, parte de la sensación. Sin embargo, al juzgar de los datos que provienen de la sensación, el alma llega a darse cuenta de que está haciendo uso de criterios que la transcienden a ella misma. Por ejemplo, cuando se pregunta "¿Sócrates es bueno?", debe sucesivamente preguntarse "¿cómo el pensamiento tiene en sí el Bien?”.

Es claro que, para eso, debe recurrir a los Inteligibles presentes en la Inteligencia. Y así surge la pregunta: “¿La Inteligencia es una parte del Alma?”; o en otras palabras: “¿La Inteligencia es nuestra?”. La respuesta a esta pregunta es de especial interés: en un sentido, Plotino afirma que la Inteligencia sí "es nuestra", pues tenemos a ella libre acceso, la tenemos a disposición. Sin embargo, por otro lado "no es nuestra", pues no siempre estamos en sintonía con ella; y no es ella la que se abaja a nosotros, sino que somos nosotros que debemos conformarnos a ella: "es nuestra y no es nuestra". En otras palabras, la Inteligencia es superior a nosotros, pues tiene evidentemente una función normativa con respecto a nuestra razón discursiva. En breve: "Si la sensación es para nosotros un mensajero, la Inteligencia es para nosotros un Rey"23.

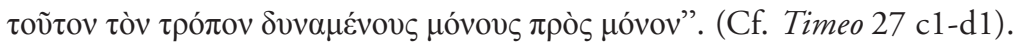

22 Cf. Plotino, Enéada V, 3, 10.12.

23 Plotino, Enéada V, 3, 3, 45-46. Cf. Platón, Filebo 28c. 
Con todo, dice Plotino, también nosotros podemos ser Reyes, si nos conformamos a la Inteligencia. Eso se realiza de dos maneras:

"[...] o por medio de las letras que están escritas en nosotros como leyes, o porque somos llenados por ella, y somos capaces de verla y advertir su presencia. Y así nos conocemos a nosotros mismos, pues, por medio de tal visión, conocemos todas las demás cosas [...]. Así, el que se conoce a sí mismo es doble: por un lado, es el que comprende la facultad racional del alma; por otro lado, es algo de valor superior, que se conoce a la manera de la Inteligencia, habiéndose cambiado en Ella. Por consecuencia, ya no se piensa como hombre, sino que, transformado en otra naturaleza y elevado hacia lo alto, ha llevado consigo solo la parte mejor del Alma, la única que es capaz de emprender el vuelo hacia el conocimiento directo (nóesis), para depositar en él lo que ha visto allí arriba”24.

En otras palabras, en el proceso de autoconocimiento, el Alma va descubriendo que ella, al ser una imagen de la Inteligencia, lleva en sí misma, casi en forma de una inscripción, la totalidad de las cosas: al descubrir eso, se pone naturalmente en movimiento el deseo de ascensión hacia Aquello que nos permite tener tales inscripciones, es decir al Autor de un tal maravilloso texto, que es por supuesto, la Inteligencia. Este movimiento es el que lleva al Alma a volverse Inteligencia. Y así, en palabras de Plotino, "con la Inteligencia mira a la Inteligencia: es decir, consigo misma se mira a sí misma” 25 .

Lo cual significa que el autoconocimiento y el volverse Inteligencia son, en suma, la misma cosa: el proceso de conocerse a sí mismo involucra necesariamente el "volverse Inteligencia". A esto, Plotino agrega una consideración metafísica ulterior, de gran profundidad.

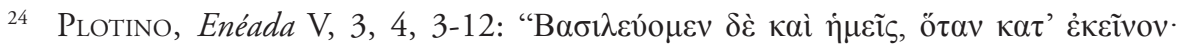

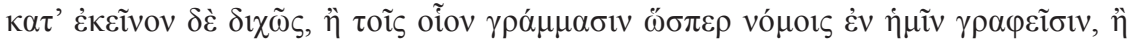

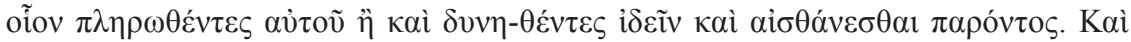

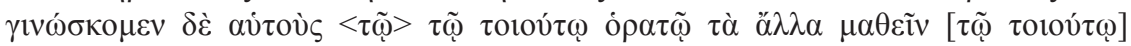

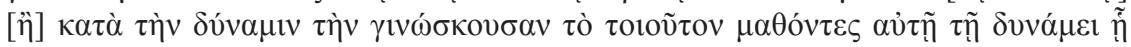

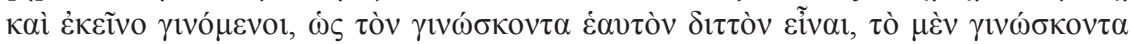

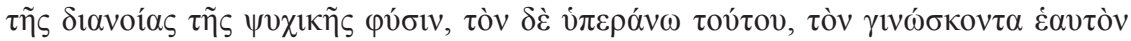

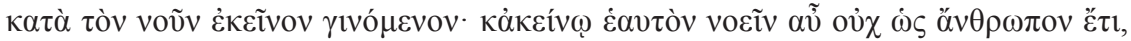

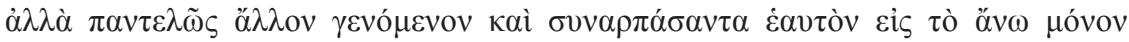

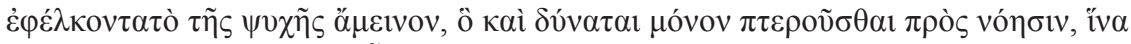

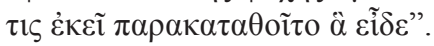

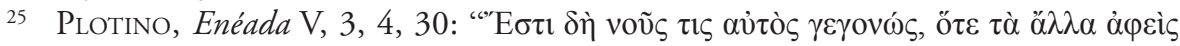

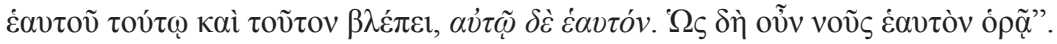


En efecto, el autoconocimiento del alma, como ya lo intuía Platón, implica una paradoja, pues implica una especie de desdoblamiento. Ahora bien, de este desdoblamiento del Alma debe decididamente excluirse, argumenta Plotino, una partición del alma, por la cual una parte sería el objeto y otra el sujeto de la contemplación. Pero también el verse entera del alma a sí misma le resulta problemático, pues se vería como contemplada y no como contemplante al mismo tiempo. Para resolver este problema, debe suponerse que ella se ve al mismo tiempo como contemplante, y esto, entonces, incluye en la contemplación también todas las demás realidades contempladas en el conocimiento: estas, por su parte, no deben concebirse como meras imágenes, sino como las realidades mismas objetos del conocimiento. En otros términos, deben estar incluidos en este acto de autoconocimiento todos los Inteligibles como tales, lo cual significa toda la Inteligencia como tal, pues la Inteligencia y los Inteligibles son en definitiva, la misma realidad. El proceso de autoconocimiento, por lo tanto, reenvía necesariamente a una Realidad que se autoconoce en sentido perfecto y originario.

Pocas páginas después, en el capítulo $8^{\circ}$ ) Plotino vuelve a expresar el mismo concepto en los términos de la Iluminación. El Alma, para poder ver cualquier realidad inteligible, y por tanto también para poder verse a sí misma, necesita de la Iluminación. En palabras de Plotino: "Esta luz, resplandeciendo en el Alma, la iluminó, es decir, la hizo inteligente, haciéndola semejante a si misma, que es Luz de naturaleza superior [...]"26.

"Así, también nuestra alma sube hacia la Inteligencia, reconociéndose imagen suya y juzgando su vida como una proyección y un retrato suyo [...]. Y, si se interrogara esta Alma sobre la naturaleza de aquella Inteligencia perfecta y universal, que desde el origen se conoce a sí misma, el Alma primero debería colocarse en la Inteligencia, delegándole la actuación de aquellas cosas de las que tenía recuerdo, de modo que sea posible, de alguna manera, ver la Inteligencia a través del Alma que es su imagen, o, mejor dicho, a través de aquella Alma que se ha asemejado a ella lo más posible, por cuanto es posible a una parte del Alma asemejarse a ella" 27 .

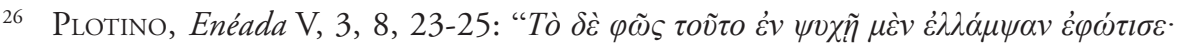

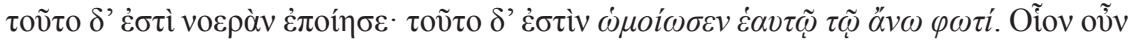

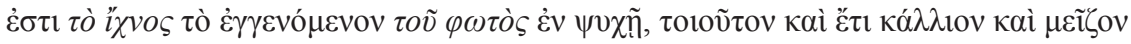

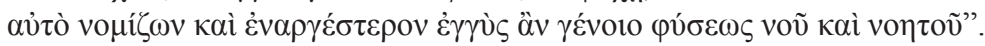

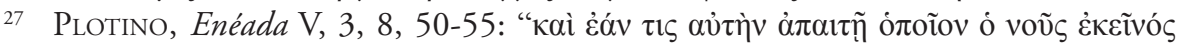

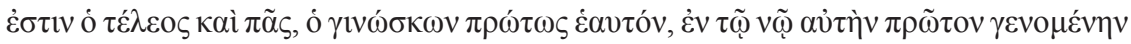


Como se ve, es difícil exagerar la importancia de estas reflexiones para la profundización filosófica, en ámbito cristiano, de la doctrina bíblica del hombre como imagen y semejanza de Dios.

\section{SER EN RELACIÓN Y CONOCIMIENTO DE SÍ EN EL DE TRINITATE DE SAN AGUSTÍN}

La deuda de Agustín con los neoplatónicos en este tema específico ha sido objeto de estudios detallados ${ }^{28}$. No es nuestra intención aquí retomar este análisis en detalle, sino solo evidenciar el fundamento más profundo de la doctrina del autoconocimiento, tal como se esboza en los libros VIII-IX del De Trinitate. Sobre esta base, intentaremos un balance sintético del significado metafísico general del punto central de la doctrina agustiniana del autoconocimiento, más bien enfatizando su diferencia con respecto al maestro neoplatónico. En efecto, esperamos evidenciar que, a pesar de los evidentes influjos platónicos, es justamente a partir del replanteamiento radical de este problema que Agustín imprime a toda su filosofía un rumbo no solo distinto, sino incluso netamente contrario a la sistematización neoplatónica. Tal diferencia necesita tanto más ser evidenciada, porque en el De Trinitate (a diferencia del De Civitate Dei) faltan indicaciones polémicas explícitas de parte del autor.

Para poner estos textos en la justa perspectiva, finalmente, será necesario analizar algunas referencias a libros XIV-XV del De Trinitate, teniendo en cuenta que estos fueron redactados en una segunda y definitiva etapa de composición.

Hasta el libro VII, Agustín ha desarrollado el plan que había trazado al comienzo de la obra: definir y sistematizar del modo más cuidadoso posible, en base a una amplísima colección de pasajes bíblicos, la doctrina de la fe católica sobre la Santísima Trinidad. En particular, en los libros V-VII ha profundizado de un modo especialmente detallado la doctrina de las relaciones trinitarias en relación con la única sustancia, doctrina que resume brevemente al comienzo del libro:

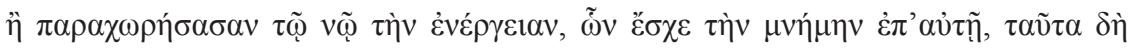

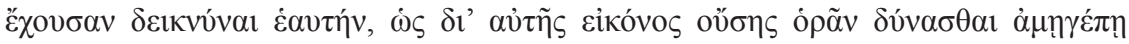

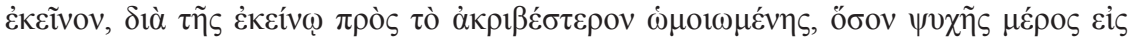

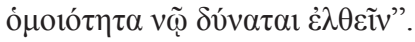

28 Véase en particular la serie de artículos de Edward BоOTH, St Augustine’s "notitia sui" Related to Aristotle and the Early Neoplatonists (Augustiniana 27 1977, 70-132. 164-401; 28 1978, 183-221; 29 1979, 97-124). 
"Hemos afirmado en otro lugar que, en aquella Trinidad, se dicen propiamente de manera distinta los atributos pertenecientes a cada una de las Personas, que se afirman de la una relativamente a la otra, como 'Padre' e 'Hijo', y 'Don' de ambos, el Espíritu Santo; en efecto, el Padre no es la Trinidad, ni el Hijo es la Trinidad, ni la Trinidad es el Don. En cambio, lo que cada una de las Personas se dice en sí misma, no se dice tres, en plural, sino que la misma Trinidad es una sola cosa: así como se dice Dios el Padre, Dios el Hijo, Dios el Espíritu Santo; bueno el Padre, bueno el Hijo, bueno el Espíritu Santo; y omnipotente el Padre, omnipotente el Hijo, omnipotente el Espíritu Santo. Y, sin embargo, no se habla de tres Dioses, ni de tres buenos, ni de tres omnipotentes, sino de un solo Dios, bueno, omnipotente: la misma Trinidad. Así como cualquier otro atributo que no se dice del uno relativamente al otro, sino que de cada Persona en sí. Estos atributos en efecto, se dicen según la esencia, pues aquí 'ser' es lo mismo que 'ser grande', 'bueno', 'sabio', y cualquier otro atributo que se diga de cada Persona en sí misma, o de la misma Trinidad" 29.

He aquí la síntesis que Agustín acaba de realizar, fundándose en los grandes debates que habían ocupado la mayor parte del siglo anterior, y habían resultado en las decisivas formulaciones dogmáticas de los concilios de Nicea y Constantinopla. Precisamente al Hiponense le tocará la tarea de mostrar el impacto decisivo que la doctrina trinitaria podía tener también en la profundización de la doctrina metafísica sobre Dios y sobre el hombre: es decir, sobre la teología natural y la antropología filosófica.

En efecto, Agustín marca aquí el inicio de una mayor profundización, "de manera más interior", afirma, de las verdades ya estudiadas; aunque se trate de las mismas realidades, y recalcando que deberá mantenerse firme la regla que dicta la adhesión a las verdades de fe.

Si bien, a primera vista, no resulta inmediatamente evidente el significado de la expresión "modo interiore", este se aclara evidentemente con el contexto de los siguientes libros, que serán un itinerario a través de la interioridad humana, para descubrir la trinidad que el hombre es, al mismo tiempo realidad e imagen para llegar a una comprensión racional, por lo que es posible, de la Trinidad divina.

29 S. Aurelius Augustinus, De Trinitate (Ed. Corpus Christianorum, Series Latina L, W.J. Mountain-Fr. Glorie, Turnholti, Brepols 1968), VIII, i, 1. 
A continuación, Agustín pasa a subrayar la característica principal de la Esencia divina como esencia de la Verdad: en esta se funda, para la razón natural, la igualdad y consustancialidad de las tres Personas divinas. El Padre no tiene "más grandeza" que el Hijo pues no tiene "más verdad" que Él; ni tampoco ambos juntos, el Padre y el Hijo, tienen mayor verdad que el Espíritu Santo, por tanto, tampoco tienen mayor grandeza ${ }^{30}$.

En las realidades corpóreas, en cambio, puede suceder que una realidad de una misma especie sea más grande que otra. Para un objeto de oro, por ejemplo, no es lo mismo ser "de oro" que "ser grande": un objeto puede tener mayor cantidad de oro que otro.

Veamos ahora el análisis del alma: aquí no hay una cantidad material que sea mayor que otra, pues el alma es inmaterial ${ }^{31}$. Sin embargo, para el alma humana, no es lo mismo ser, o ser verdadera, que ser grande. El alma por cierto, es como sustancia espiritual, pero es mudable, y este es el principal atributo que la distingue de Dios: "Todo lo que, en las realidades espirituales, se nos presente como mudable, no debe ser considerado Dios"32.

Ella, además, es ofuscada por las "nubes de las imágenes corporales", $\mathrm{y}$ angustiada por las muchas preocupaciones terrenales ${ }^{33}$.

Con todo, a través de la consideración de la bondad de todas las variadas realidades creadas, de las que Agustín ofrece aquí una larga y poética enumeración, casi un 'Cántico de las creaturas' ${ }^{34}$, es posible finalmente vislumbrar el Bien en sí. Concluye:

“¿Para qué agregar más y más cosas? Bueno es esto y aquello. Deja de lado esto y aquello, y mira al Bien mismo, si puedes: así verás a Dios, que no es bueno por otro bien, sino que es el Bien de todo bien. Y en efecto, en

\footnotetext{
Cf. Trin. VIII, i, 2.

La demostración de este punto se ofrecerá en el Libro X.

32 Trin. VIII, ii, 3, 14-15 "In spiritalibus autem omne mutabile quod occurrerit non putetur Deus".

33 Trin. VIII, ii, 3, 28-29. Cf. Sap 9, 15.

34 Trin. VIII, iii, 4, 2-14 "[...] buena la tierra, la altura de los montes, la dulzura de las colinas, [...] bueno el campo ameno y fértil, los animales, el aire [...], buena la comida sabrosa y saludable, buena la misma salud corpórea, [...] bueno el rostro humano bien proporcionado y alegre [...], buena el alma del amigo y la dulzura de la concordia, buena la fidelidad en el amor, bueno el cielo, el sol, la luna, las estrellas; buenos los ángeles con su santa obediencia, bueno el discurso que enseña suavemente y conmueve al que escucha, bueno el poema musical con sus ritmos $[\ldots] "$.
} 
todos estos bienes que he recordado, u otros que pueden contemplarse o pensarse, no podríamos decir que uno es superior a otro, cuando juzgamos de ellos con verdad, si no tuviéramos impresa en nosotros la noción del Bien mismo, según la cual apreciar o preferir algo" 35 .

En lo que se refiere al alma humana, por lo tanto, como para toda realidad creada, una cosa es ser alma, otra cosa es ser buena. Pero, en el caso de ella, se da una circunstancia particular: el alma es sin duda un bien, por la misma creación, pues participa del Bien en sí: esto no depende de ella, sino que es algo que ella pasivamente recibe. Sin embargo, ella puede activamente, con un acto de la voluntad, dirigirse a aquel Sumo Bien (conversio) que la ha traído al ser, y así alcanzar la bienaventuranza; y no solo puede, sino que debe, pues para ese fin, precisamente, fue traída al ser. De modo que, si la voluntad se desvía del Sumo Bien dirigiéndose primariamente a otros bienes (aversio), ella es justamente culpada y definida mala. Pues, a pesar de su bondad esencial (creacional), ella no alcanza el objetivo para el cual fue creada ${ }^{36}$.

De lo anterior se deduce, en cuanto al conocimiento de sí, que el alma no puede ella misma llegar a conocerse, si no es por relación con aquella escala de bienes que solo es visible por la noción del Bien mismo, que es impresa en el alma por naturaleza, y que es equivalente a la noción de la Verdad: el alma no la podemos contemplar o valorar "en sí misma" (o sea: respecto de sí misma), sino solo: "en aquel Arte en la que ha sido creada: pues se aprueba, una vez creada, allí mismo donde se contempla que tenía que crearse: esta es la Verdad y el Bien simple" ${ }^{37}$.

Naturalmente, esto no significa para Agustín que el alma, durante la vida terrenal, pueda tener una visión directa de lo que se contempla en el Arte eterno; pero sí que la luz natural del entendimiento, "que ilumina todo hombre que viene a este mundo", es un reflejo y una participa-

35 Trin. VIII, iii, 4, 14-21 "Quid plura et plura? Bonum hoc et bonum illud. Tolle hoc et illud, et vide ipsum Bonum, si potes; ita Deum videbis, non alio bono bonum, sed Bonum omnis boni. Neque enim in his omnibus bonis, vel quae commemoravi, vel quae alia cernuntur sive cogitantur, diceremus aliud alio melius cum vere iudicamus, nisi esset nobis impressa notio ipsius boni, secundum quod et probaremus aliquid, et aliud alii praeponeremus".

36 Cf. Trin. VIII, iii, 4-5.

37 Trin. VIII, iii ,5, 58-61: "non in se ipso nobis placet sed in illa arte qua factus est. Inde enim approbatur factus, ubi videtur fuisse faciendus. Haec est veritas, et simplex bonum". 
ción especial, que caracteriza específicamente el ser humano, del "libro de aquella Luz, que se llama la Verdad" donde todo está escrito ${ }^{38}$. Esta impresión de la Verdad en el alma, como de un anillo en la cera, es precisamente lo que le permite al alma conocerse a sí misma. Por un lado, le permite apreciar su bondad creacional, superior a las piedras, a las plantas, a los animales y a su propio cuerpo; por otro, le permite valorar el camino para el cual está hecha, y tener una idea del bien y la felicidad que la espera, a la vez que le permite juzgar en qué etapa del camino se halla, y si se está moviendo en la dirección correcta. El alma nunca puede perder el contacto con esta luz, por muy alejada que se encuentre. Se trata de una lux sui generis ${ }^{39}$, no solamente incorpórea, sino, además, ciertamente superior al alma en su inmutabilidad e infalibilidad. La precisión "sui generis" destaca que no se trata de una luz creada-pues ninguna creatura es inmutable como la luz inteligible- pero por cierto tampoco se trata de la Luz increada vista en su realidad. Se trata por lo tanto de una anticipación virtual, por así decir, que nos permite acceder a los criterios básicos de juicio sobre la realidad, que están inscritos en el Verbo divino. La percepción de la luz inteligible, común a todo ser humano, si bien proporciona la condición metafísica necesaria que posibilita el ascenso del alma humana a la Verdad, no es seguramente condición suficiente.

Sin embargo, a esta anticipación virtual de la luz sobrenatural se acompaña también una acción real del alma, que, al conocer el criterio de la justicia, ama a las personas justas y las ama necesariamente en relación con la misma justicia: es decir se aman a las personas porque son justas, o para que sean justas. Si no se amara a una persona (incluyendo a uno mismo) con este criterio, en estricto rigor no se la está amando: lo que se da en ese caso es un mero deseo pasional (cupiditas). La razón es simple: ser justo representa el bien para la persona: si no se quiere que sea buena, o hasta se quiere que no lo sea, no se quiere su bien, por lo

38 Cf. Trin. XIV, xv, 21, 47-55: "Ubinam sunt istae regulae scriptae, ubi quid sit iustum et iniustus agnoscit, ubi cernit habendum esse quod ipse non habet? Ubi ergo scriptae sunt, nisi in libro lucis illius quae Veritas dicitur? unde omnis lex iusta describitur, et in cor hominis qui operatur iustitiam, non migrando, sed tamquam imprimendo transfertur, sicut imago ex anulo et in ceram transit, et anulum non relinquit? Qui vero non operatur, et tamen videt quid operandum sit, ipse est qui ab illa luce avertitur, a qua tamen tangitur".

39 Cf. Trin. XII, xv, 24, 15: "in quadam luce sui generis incorporea”. 
tanto, no se le quiere bien, sino que se la odia (o se odia a uno mismo) ${ }^{40}$. Es, por tanto, en virtud de una visión interior, la de la forma misma de la justicia, y además por medio del amor de esta forma, que uno puede amarse a sí mismo y amar al prójimo: pero a esta forma no se la ama en virtud de otra cosa, sino en virtud de sí misma ${ }^{41}$.

Esta reflexión explica perfectamente por qué el doble mandato del amor a Dios y el amor al prójimo forman en realidad una sola cosa, porque quien se ama a sí mismo, o a otro, en primer lugar ama al mismo amor. Pero el Amor, en último término, es Dios mismo: por tanto, todo el que ama, ama precipuamente a $\operatorname{Dios}^{42}$. Por cierto, el puro y verdadero amor no es el amor en un plano meramente natural, pues necesita de la Gracia: será necesaria, para eso, la presencia real de la Trinidad misma en el alma, como veremos más adelante, en el libro XIV. Sin embargo, es de subrayar que ya en este contacto virtual y natural del alma con la Verdad y en su amor a la Bondad, se define en su esencia el ser relacional del alma humana y se posibilita su primer acto de autoconocimiento y amor. Se trata de una predisposición o prefiguración de la inhabitación trinitaria en el alma, que configurará la semejanza propiamente tal con Dios.

Aclarados tales fundamentos en el libro VIII, en el IX Agustín emprende la tarea de mostrar explícitamente la imagen de la Trinidad en el alma, que lo ocupará en todo el resto de la obra, en diferentes niveles.

En primer lugar la mente, al conocerse a sí misma, produce una objetivación, que es como una segunda dimensión: una notitia, justamente, con

40 Trin. VIII, vi, 9, 134-140: "Qui ergo amat homines, aut quia iusti sunt, aut ut iusti sint, amare debet. Sic enim et se ipsum amare debet, aut quia iustus est, aut ut iustus sit; sic enim diligit proximum tamquam se ipsum, sine ullo periculo. Qui enim aliter se diligit, iniuste se diligit, quoniam se ad hoc diligit ut sit iniustus; ad hoc ergo ut sit malus, ac per hoc iam non se diligit: Qui enim diligit iniquitatem, odit animam suam. (Psal 10, 6)".

41 Trin. VIII, vi, 9, 122-130: "Cur ergo alium diligimus quem credimus iustum, et non diligimus ipsam formam ubi videmus quid sit iustus animus, ut et nos iusti esse possimus? An vero nisi et istam diligeremus, nullo modo eum diligeremus quem ex ista diligimus, sed dum iusti non sumus, minus eam diligimus quam ut iusti esse valeamus? Homo ergo qui creditur iustus, ex ea forma et veritate diligitur, quam cernit et intellegit apud se ille qui diligit, ipsa vero forma et veritas non est quomodo aliunde diligatur. Neque enim invenimus aliquid tale praeter ipsam, ut eam, cum incognita est, credendo diligamus, ex eo quod iam tale aliquid novimus". 
la que se conoce. A continuación, amándose a sí misma, el propio amor constituye una tercera dimensión, en la única sustancia que es el alma:

"Tal como son dos, la mente y su amor, cuando ella se ama; así también son dos, la mente y su conocimiento, cuando se conoce. Por tanto, la mente, el conocimiento y el amor son tres, y estos tres son una sola cosa, y dado que son perfectos, son iguales" ${ }^{43}$.

Agustín precisa que de lo anterior se deduce también que estas tres predicaciones del sujeto humano (mens, notitia, amor), que indican una interna relacionalidad, no son predicaciones accidentales, sino que son predicaciones sustanciales:

"El amor y el conocimiento no están en la mente como en un sujeto, sino que existen de un modo sustancial, tal como la misma mente; porque, aunque se dicen relativamente el uno al otro, cada uno de ellos sin embargo existe en su propia sustancia" ${ }^{44}$.

Agustín corrige aquí la suposición implícita en las Categorías aristotélicas, según la cual la categoría de sustancia es separada de la categoría de relación. La substantia, en efecto, es aquello que subsiste por sí mismo, y se dice en relación solo cuando entra en contacto con otras sustancias. Aquí, en cambio, se está hablando de una relación constitutiva de la sustancia misma del alma humana.

Sin embargo, esto no significa que la relacionalidad interna del alma se pueda comprender como encerrada en sí misma o autosuficiente. Tampoco significa, y esto se quiere aquí especialmente subrayar, que la trinidad que constituye el alma humana pueda generarse o desarrollarse en un nivel puramente horizontal, sin la dimensión siempre presente de la relación con el Creador. Ciertamente Agustín, preocupado de mostrar el paralelo entre la trinidad humana y la Trinidad divina, afirma aquí que se da una consustancialidad de estas tres dimensiones, y que la mente genera una noticia igual a sí misma: "La mente, cuando se conoce a sí

43 Trin. IX, iv, 4, 1-5: "Sicut autem duo quaedam sunt, mens et amor eius, cum se amat; ita quaedam duo sunt, mens et notitia eius, cum se novit. Ipsa igitur mens et amor et notitia eius tria quaedam sunt, et haec tria unum sunt, et cum perfecta sunt, aequalia sunt".

44 Trin. IX, iv, 5, 36-39: "non amor et cognitio tamquam in subiecto insunt menti, sed substantialiter etiam ista sunt, sicut ipsa mens; quia et si relative dicuntur ad invicem, in sua tamen sunt singula quaeque substantia”. 
misma, no se supera con la noticia de sí misma; pues ella conoce, ella misma es conocida" 45 .

Y poco antes había afirmado:

"La mente misma, así como recoge las noticias de las cosas corpóreas mediante los sentidos del cuerpo, así [recoge las] de las incorpóreas por sí misma. Por tanto, también se conoce a sí misma por sí misma, pues es incorpórea" 46 .

Sin embargo, para evitar entender mal estas afirmaciones, como si la generación de esta notitia sui fuera un acto totalmente autónomo de la creatura racional, debemos tener siempre presentes los presupuestos planteados en el libro anterior: es en la eterna verdad, donde vemos la forma según la que somos; es de ahí que podemos concebir una noticia veraz de las cosas (incluyendo por cierto a nosotros mismos), que generamos interiormente como un verbo, que, una vez generado, no se aleja de nosotros ${ }^{47}$.

Este verbo interno, además, se concibe en el amor, como precisa más adelante ${ }^{48}$.

Es correcto decir, por tanto, que la mente concibe una noticia de sí igual a ella misma, y por eso no se supera a sí misma: no se supera, pues se conoce verdaderamente a sí misma, tal como es. Pero el conocimiento es siempre, por los supuestos recordados, algo como un verse en el espejo de la eterna Sabiduría, aunque inicialmente de un modo oscuro e inconsciente; o, mejor dicho, siendo ella misma como un espejo de la eterna Sabiduría; y no pura y simplemente en sí misma.

¿Por qué entonces, en la afirmación citada, Agustín dice que "el alma se conoce a sí misma por sí misma”? Esto se explica adecuadamente,

45 Trin. IX, iv, 4, 19-21: "Mens vero cum se ipsa cognoscit, non se superat notitia sua; quia ipsa cognoscit, ipsa cognoscitur".

46 Trin. IX, iii, 3, 16-19: "Mens ergo ipsa sicut corporearum rerum notitias per sensus corporis colligit, sic incorporearum per semetipsam. Ergo et se ipsam per se ipsam novit, quoniam est incorporea".

47 Trin. IX, vii, 12, 1-6. "In illa igitur aeterna veritate, ex qua temporalia facta sunt omnia, formam secundum quam sumus, et secundum quam vel in nobis vel in corporibus vera et recta ratione aliquid operamur, visu mentis aspicimus; atque inde conceptam rerum veracem notitiam, tamquam verbum apud nos habemus, et dicendo intus gignimus; nec a nobis nascendo discedit”.

48 Trin. IX, vii, 13, 15-17: "Quod verbum amore concipitur, sive creaturae, sive Creatoris, id est, aut naturae mutabilis, aut incommutabilis veritatis". 
si se tiene presente el contexto, que contrapone el conocimiento que el alma tiene de las cosas corpóreas, por medio de los sentidos, con el conocimiento que tiene de sí misma, que no tiene necesidad de intermediarios: así como hay un contacto con las cosas por medio de los sentidos exteriores, así hay un contacto del alma consigo misma, sin necesidad de los sentidos. Pero contacto no es lo mismo que conocimiento: cuando dice que el alma se conoce "a sí misma por sí misma”, está diciendo que se conoce por medio de una experiencia interior y no por medio de los sentidos, pero debe tenerse presente que ella no se conoce de un modo autosuficiente, sino siempre a la luz de la verdad inmutable, que le dice "cómo es y cómo debe ser". La mera presencia del alma a sí misma no bastaría en ningún caso para autoconocerse, así como las impresiones recibidas de los sentidos no bastarían en ningún caso para producir los conceptos de las cosas. En otras palabras, la notitia del alma, con la que el alma se conoce a sí misma, necesita, como cualquier otro conocimiento humano, de aquella conexión con las realidades inteligibles (res intelligibiles, o rationes aeternae), conexión que fundamenta su naturaleza inteligente ${ }^{49}$.

A la luz de lo anterior, debe interpretarse también la conclusión que de todo este razonamiento Agustín nos ofrece al final del libro IX. Agustín procede del modo siguiente: cuando conocemos algo inferior a nosotros, el conocimiento de esa realidad es superior a la realidad misma, pues está en nosotros, que somos una naturaleza superior; cuando conocemos a Dios, que es superior a nosotros, este conocimiento es inferior a la realidad misma, pues se halla en una realidad inferior: en cambio, el

49 Trin. XII, xv, 24, 13-16: "Sed potius credendum est mentis intellectualis ita conditam esse naturam, ut rebus intelligibilibus, naturali ordine, disponente conditore, subiuncta, sic ista videat in quadam luce sui generis incorporea, quemadmodum oculus carnis videt quae in hac corporea luce circumadiacent, cuius lucis capax eique congruens est creatus".

La palabra "potius", que introduce el pasaje, expresa la contraposición del planteamiento agustiniano con la teoría platónica de la preexistencia del alma, basada en la necesidad de una previa visión de las ideas en una vida precedente. Agustín valora plenamente la instancia platónica de explicar la proveniencia de los conceptos de la mente como entidades que transcienden la realidad empírica, pero considera que se puede dar conveniente razón del fenómeno postulando esta conexión natural de la mente, por creación, con las realidades inteligibles. De este modo adopta una explicación más racional, porque más económica, que evita sobre-explicar el fenómeno. 
conocimiento que el alma tiene de sí misma se encuentra en una realidad del mismo nivel, pues se trata de ella misma. Conclusión:

"De lo cual se deduce que, cuando la mente se conoce y se aprueba a sí misma, esta misma noticia es el verbo de ella, de tal manera que le sea del todo par e igual, y viceversa; porque ni es conocimiento de una esencia inferior, como del cuerpo; ni de una superior, como es la de Dios. Y como la noticia tiene semejanza respecto de la realidad que conoce, es decir, cuya noticia es, esta tiene una noticia perfecta e igual, por la que la misma mente que conoce, es conocida. Y, por lo tanto, es tanto imagen como verbo, porque se expresa a partir de ella, cuando, al conocer, se adecua a ella misma, y lo que es generado es igual a lo que genera" ${ }^{50}$.

Y poco después, al terminar el libro IX:

"Y es una cierta imagen de la Trinidad, la misma mente, y su conocimiento, que es su prole, y su verbo [generado] de ella misma, y tercero, el amor; y estos tres son una sola cosa y una sola sustancia. Y la prole no es menor que ella, pues la mente se conoce en la misma medida que es; ni es menor el amor, pues se ama en la misma medida en que se conoce y es" ${ }^{\prime \prime}$.

En este planteamiento se aprecia ya con perfecta claridad la distancia que lo separa del itinerario neoplatónico. El alma no se vuelve Inteligencia, como en Plotino, sino que genera a su propio verbo, a imagen de su sustancia, igual a ella, y así también el amor. Esto pone en clara luz la existencia del hombre como un ser que tiene su propia subsistencia distinta de la Trinidad divina: la trinidad en el hombre es una trinidad creada, imagen infinitamente distante del modelo superior y eterno, la

50 Trin. IX, xi, 16, 18-26: "Ex quo colligitur, quia cum se mens ipsa novit atque approbat, sic est eadem notitia verbum eius, ut ei sit par omnino et aequale, atque identidem; quia neque inferioris essentiae notitia est, sicut corporis; neque superioris, sicut Dei. Et cum habeat notitia similitudinem ad eam rem quam novit, hoc est, cuius notitia est; haec habet perfectam et aequalem, qua mens ipsa, quae novit, est nota. Ideoque et imago et verbum est, quia de illa exprimitur cum cognoscendo eidem coaequatur, et est gignenti aequale quod genitum est".

51 Trin. IX, xii, 18, 75-80: "Et est quaedam imago Trinitatis, ipsa mens, et notitia eius, quod est proles eius ac de se ipsa verbum eius, et amor tertius, et haec tria unum atque una substantia. Nec minor proles dum tantam se novit mens quanta est; nec minor amor, dum tantum se diligit quantum novit et quanta est”. 
Trinidad divina. Sin que esto signifique, como hemos subrayado, que sea autónoma ${ }^{52}$ en su dinamismo y en sus operaciones.

Debe observarse, en suma, el magistral equilibrio con que Agustín complementa las profundas intuiciones neoplatónicas sobre la necesidad que el alma tiene de encontrar su identidad en la contemplación de lo divino en sí misma, y la necesidad igualmente importante de mantener su estatus fundamental de creatura.

Para completar nuestro itinerario en el contexto del De Trinitate, traeremos ahora a colación algunos importantes pasajes de los libros finales del tratado, que expresan sin duda la fase más madura y definitiva de su desarrollo.

En el libro XIV, subrayaremos en particular el capítulo donde se pone el problema que ya hemos visto en los textos de Platón y Plotino: la paradoja subyacente a la posibilidad de que el alma se vea a sí misma. Siguiendo a Plotino, Agustín excluye que el alma pueda dividirse, de modo que una parte de ella pueda ver a otra parte; también excluye que pueda desdoblarse, para que pueda ser al mismo tiempo la que ve y la que es vista:

"Tan grande es la fuerza del pensamiento, que ni siquiera la mente misma puede ponerse ante su propia mirada, sino cuando se piensa a sí misma; y por eso, no hay nada ante la mirada de la mente, sino desde el momento en que se piensa, hasta tal punto, que ni siquiera la mente misma, con la que se piensa todo lo que se piensa, puede estar de otra manera ante su propia mirada, sino pensándose a sí misma. Pero de qué manera, cuando no se piensa a sí misma, no esté ante su propia mirada, dado que ella nunca puede estar sin ella misma, como si una cosa fuera ella misma, y otra cosa su propia mirada, no logro encontrarlo. Esto por cierto se dice, sin que sea absurdo, del ojo del cuerpo. Pues el mismo ojo, ciertamente, está colocado en el cuerpo en su lugar; pero su mirada se dirige hacia las cosas externas y se extiende hasta las estrellas. Y el ojo no está ante su propia mirada, cuando no se mira a sí mismo, excepto si se pone delante de un espejo, como ya hemos observado. Lo cual no ocurre, ciertamente, cuando la mente se pone, con el pensamiento, ante su propia mirada. ¿Acaso entonces ella ve con una parte de sí misma a otra parte, cuando se mira pensándose, tal como con algunos miembros nuestros,

52 En todo este contexto, tomamos la palabra autónomo en su sentido estricto, etimológico: "que se da ley a sí mismo". 
como son los ojos, miramos otros miembros nuestros que pueden estar ante nuestra vista? ¿Qué puede decirse o pensarse más absurdo? ¿De dónde entonces se retira la mente, sino de sí misma, y dónde se pone ante su propia mirada, sino ante sí misma? Entonces, ¿acaso ella no estará donde estaba cuando no estaba ante su mirada, dado que ha sido puesta aquí y removida de allí? Pero, si ha emigrado para ser mirada, ¿¿ónde permanecerá para mirar? ¿Acaso, por así decir, se desdobla, para estar tanto allí como aquí, es decir, donde pueda mirar y donde pueda ser mirada, para que en sí misma sea vidente y ante si misma visible?" 33 .

A pesar de la clara influencia de los textos platónicos, vemos en un pasaje como este la manera típicamente agustiniana de repensar un tema desde su fundamento y de analizarlo de manera personal en todos sus aspectos. La mente humana, ciertamente, es capaz de mirarse a sí misma, pero solo puede hacerlo en la medida en que se piensa a sí misma; y esto es fruto de un proceso, mediante el cual ella se coloca ante su propia mirada, es decir, dirige el pensamiento hacia sí misma. De esto podemos deducir que el autoconocimiento no es algo necesario o esencial, ni simplemente automático en el hombre. Ciertamente es parte del anhelo general de conocer, pero exige un esfuerzo particular y voluntario: se trata de una conversión incorpórea, que puede darse gracias al carácter espiritual del alma. En definitiva, las mencionadas aporías nacían del imaginar falsamente el proceso del alma como si fuera algo material, como si ella materialmente necesitara trasladarse ante su propia mirada: es necesario, en cambio, superar "las falsas imágenes de los cuerpos" y considerar que se produce, en este caso, el conocimiento de aquella misma individualidad incorpórea del alma, mediante la cual conocemos todas las cosas:

"Por lo cual, queda que su mirada sea algo que pertenece a su naturaleza, y hacia ella, cuando se piensa a sí misma, es conducida, no a través de un espacio físico, sino mediante una conversión incorpórea" 54 .

El autoconocimiento del alma, sin embargo, no produce algo absolutamente nuevo y desconocido para el alma, sino que preexiste, de

53 Trin. XIV, vi, 8, 1-24.

54 Trin. XIV, vi, 8, 29-31: "Proinde restat ut aliquid pertinens ad eius naturam sit conspectus eius, et in eam, quando se cogitat, non quasi per loci spatium, sed incorporea conversione revocetur". 
manera misteriosa, en lo que se llama la memoria ${ }^{55}$. Por cierto, el conocimiento de la propia esencia no puede venir de la nada, sino que es de algún modo generado de esta misma esencia; esto permite que la persona se auto-reconozca y finalmente se ame a sí misma: así se forma -o se empieza a formar- la trinidad en el hombre

"Por eso recordábamos la trinidad, de modo que aquello de donde se forma la mirada del que piensa, la identificamos con la memoria; la misma conformación, como una imagen que de allí se imprime; y aquello mediante lo cual ambos se juntan, el amor o voluntad. Por tanto, la mente, cuando se mira a sí misma con el pensamiento, se entiende y se reconoce a sí misma: por lo tanto, genera esta inteligencia y conocimiento propio. En efecto, como realidad incorpórea, se contempla en cuanto objeto de entendimiento (intellecta), y en el acto del entender (intellegendo) se conoce. Pero la mente no genera esta noticia de sí, como si antes fuera desconocida a sí misma, sino que era conocida por ella misma, al modo que son conocidas las cosas que se contienen en la memoria, aunque no se piensen. [...] Estas dos cosas, la que genera y la generada, se unen por el amor como tercero" 56 .

Existe por lo tanto un momento en que la mente es todavía, por así decirlo, inconsciente de sí misma; sin embargo, en el acto de generar su propia noticia, ella se reconoce a sí misma, signo que, de algún modo, ella ya se poseía o, en todo caso, tenía la potencialidad de generar una impresión de su propia esencia. Sin embargo, en el verbo en que ella genera su propia esencia conocida no hay una ciencia que sea solamente nuestra: aplicando a este tema la reflexión que Agustín profundizará más adelante, sobre el verbum mentis en general, podemos subrayar que nuestro verbo no nace solo de nuestra ciencia:

“¿Acaso nuestro verbo nace solo de nuestra ciencia? ¿Acaso no decimos también muchas cosas que ignoramos? Ellas, si acaso son verda-

55 Trin. XIV, vi, 8, 36-37: "cetera in arcana quadam notitia sunt recondita, quae memoria nuncupatur".

56 Trin. XIV, vi, 8, 38-45: "Ideo trinitatem sic commendabamus, ut illud unde formatur cogitantis obtutus, in memoria poneremus; ipsam vero conformationem, tamquam imaginem quae inde imprimitur; et illud quo utrumque coniungitur, amorem seu voluntatem. Mens igitur quando cogitatione se conspicit, intellegit se et recognoscit. gignit ergo hunc intellectum et cognitionem suam. Res quippe incorporea intellecta conspicitur, et intellegendo cognoscitur. [...] Haec autem duo, gignens et genitum, dilectione tertia copulantur" . 
deras, no son verdaderas en nuestro verbo; pues no es verdadero verbo, sino el que se genera de la realidad que es conocida" ${ }^{57}$.

Ahora, si aplicamos esta reflexión al tema que nos interesa, podemos ver que en el caso del alma se genera una ambigüedad, muy parecida a la que ya encontramos en Plotino. Por un lado, ciertamente, el verbo en que conocemos nuestra propia alma se genera desde esa realidad que es ella misma, y de esto ella puede tener certeza: por eso podemos decir que este verbo es nuestro ('de nosotros'). Pero a la vez, sabemos que la realidad, que ella misma es, no procede de sí misma, ni de algo que tenga su propia esencia, como el Verbo divino procede del Padre. No: ella es lo que es, en base al Verbo que la precede, y en el que su verbo particular, como verbo que dice la creatura particular que ella es, es contenido en el Verbo eterno, como lo es la imagen en el Modelo. Por consiguiente, cuando el alma dice el verbo de sí misma, ella no dice algo nuevo o autogenerado, sino que se dice a sí misma en el Verbo. En otras palabras, el alma se hace eco de la Palabra que ab aeterno la pronuncia en su existencia creada: y no solo la pronuncia en su llegar a existir inicial, sino que en todo el proyecto y la finalidad a la que el Verbo la guía y la encamina.

Su esencia más profunda, en efecto, es ser imagen de Dios: por lo tanto, conocerse verdaderamente implica conocerse como tal imagen.

De allí mismo se desprende que no le basta en absoluto al alma pensarse y amarse a sí misma, si al mismo tiempo no piensa y no ama a Dios. Y eso, porque solamente así ella llega a ser, propiamente, imagen de Dios. Leamos el siguiente pasaje, especialmente claro e iluminador:

"Por lo tanto, esta trinidad de la mente no es imagen de Dios porque la mente se acuerde de sí, se entienda y se ame, sino porque también puede recordar, entender y amar a Aquel por el cual ha sido creada. Y cuando lo hace, se vuelve sapiente. Si, en cambio, no lo hace, aun cuando se acuerda de sí, se entiende y se ama, es necia. Que se acuerde por lo tanto de su Dios, a cuya imagen ha sido hecha, lo entienda y lo ame"s8.

57 Trin. XV, xv, 24, 1-6: "Numquid verbum nostrum de sola scientia nostra nascitur? Nonne multa dicimus etiam quae nescimus? [...]: quae forte si vera sunt, in ipsis rebus de quibus loquimur, non in verbo nostro vera sunt, quia verbum verum non est, nisi quod de re quae scitur, gignitur".

58 Trin. XIV, xii, 15, 1-7: "Haec igitur trinitas mentis non propterea Dei est imago, quia sui meminit mens, et intellegit ac diligit se: sed quia potest etiam meminisse, et intellegere, et amare a quo facta est. Quod cum facit, sapiens ipsa fit. Si autem non 
Debe reflexionarse entonces que el alma humana, si bien ha sido hecha, desde su origen, a imagen de Dios, y por consiguiente lo es por naturaleza, sin embargo ella no puede conformarse con serlo de un modo auto-referente, como si pudiera conocerse solo a sí misma; de otro modo perdería o no podría adquirir conciencia de su verdadera naturaleza, que refleja la esencia de Dios de un modo activo -inteligente y voluntario-, y dinámico, en la continua tensión de conocerlo y amarlo a Él. La luz natural del intelecto, que ilumina a todo hombre, y que le permite generar la noticia de sí y el amor natural de sí, por un lado es una marca imborrable que determina su esencia, y que ningún ser humano en ningún caso puede perder, por otro tampoco le permite aquietarse en un autoconocimiento estático, como si el conocerse fuera un fin en sí mismo. Por el contrario, ella es continuamente atraída al conocimiento y al amor de Dios y, si tiene un deseo natural de conocerse y se ama, no es en última instancia por sí misma, sino porque desea conocer la Verdad y amar el Amor. Conociendo la Verdad y amando al Amor puede empezar verdaderamente a conocerse y amarse, y a ser feliz:

"[...] y no por su luz, sino por la participación de aquella Suma Luz será sapiente, y donde reinará eterna, allí reinará feliz. Así, en efecto, se dice esta sabiduría del hombre, de manera que sea también de Dios. Pues entonces es verdadera: ya que si es humana, es vana"59.

La naturaleza humana, concluye Agustín, que solo puede existir "en" Dios (in Deo), solo puede cumplir su objetivo, y por lo tanto conocerse también a sí misma en esta realización, si está "con" Dios (cum Deo): "Sin duda, en Él es, y sin Él no puede ser: y sin embargo, si no se acuerda de Él, y no lo entiende, ni lo ama, no está con Él'ro.

Su mismo autoconocimiento, en el que se cumple su verdadera identidad, depende entonces, estructuralmente, de esta relación sobrenatural, que el alma desea, sin poderla realizar con sus propias fuerzas, pero que consciente y voluntariamente puede recibir como gracia.

facit, etiam cum sui meminit, seque intellegit ac diligit, stulta est. Meminerit itaque Dei sui, ad cuius imaginem facta est, eumque intellegat atque diligat".

59 Trin. XIV, xii, 15, 10-22: "[...] et non sua luce, sed summae illius lucis participatione sapiens erit, atque ubi aeterna, ibi beata regnabit. Sic enim dicitur ista hominis sapientia, ut etiam Dei sit. Tunc enim vera est: nam si humana est, vana est".

60 Trin. XIV, xii, 16, 42-44. 
Queda reservada al último libro del De Trinitate la profundización de la metáfora del espejo, culminación de este itinerario, que aquí recordaremos solamente en su punto esencial. El texto base que Agustín tiene en mente es, naturalmente, I Cor 13, 12: Videmus nunc per speculum in aenigmate, tunc autem facie ad faciem $^{61}$.

¿Qué cosa es, exactamente, este espejo? No es difícil, para Agustín, relacionar el tema del espejo con el tema de la imagen:

"Si investigamos cuál y cómo es este espejo, ciertamente se nos ocurre, que en un espejo no se ve sino una imagen. Esto por tanto, hemos intentado hacer, para que, en esta imagen que nosotros mismos somos, viéramos de algún modo a Aquél por el cual hemos sido creados, como en un espejo" 62 .

Ahora bien, la imagen de Dios que se refleja en el hombre, es también la gloria de Dios, es decir su manifestación: el hombre es, en efecto, según el Apóstol, "imagen y gloria de Dios” (I Cor 11, 7); por otro lado, según el mismo San Pablo, aquí citado por Agustín, la imagen se realiza a través de una constante transformación, "de gloria en gloria" (II Cor 3, 18): "Nosotros, con el rostro develado, reflejando la gloria de Dios, somos transformados hacia la misma imagen, de gloria en gloria"63.

Este versículo es fundamental para la interpretación agustiniana, pues condensa en una sola frase los tres conceptos clave que le interesa recalcar: el concepto de espejo ${ }^{64}$, que es una definición de la misma alma según su interpretación de I Cor 13, 12; el concepto de imagen que se funda en la misma Divinidad (en el mismo Verbo, que es Imagen perfecta del Padre) que se refleja de modo inicialmente oscuro y enigmático en el hombre; y el concepto de transformación hacia aquella, con más y más claridad ("de gloria in gloriam"): "Dice por tanto que nos transfor-

61 Puede verse un detallado estudio diacrónico de la interpretación de este versículo en el contexto de la antropo-teología augustiniana en JÉRÔME LAGOUANÈRE, Interiorité et reflexivité dans la pensée de Saint Augustin (Institut d'Études Augustiniennes, Paris 2012), 379-574.

62 Trin. XV, viii, 14, 5-9: "Quale sit et quod sit hoc speculum si quaeramus, profecto illud occurrit, quod in speculo nisi imago non cernitur. Hoc ergo facere conati sumus, ut per imaginem hanc quod nos sumus, videremus utcumque a quo facti sumus, tamquam per speculum".

63 Citado en Trin. XV, viii, 14, 10-12.

64 Agustín precisa que "speculantes" debe interpretarse en referencia a "speculum" (espejo), y no a "specula", que significa "punto de observación". 
mamos, nos mudamos de una a otra forma, y pasamos de la forma oscura a la forma luminosa" ${ }^{65}$.

La forma oscura (este adjetivo traduce el concepto de "enigma", presente en el texto bíblico) es naturalmente la imagen inicial, impresa en la humanidad por la creación. La forma luminosa, sin embargo, donde resplandece con más claridad la imagen de Dios, puede tener diferentes sentidos, o grados:

"Esta naturaleza [humana], la más excelente entre las creadas, cuando es justificada de la impiedad, es transformada de la forma deforme a la forma hermosa (forma formosa). [...] Y por eso agregó 'de gloria en gloria’: de la gloria de la creación a la gloria de la justificación. Aunque también se puede entender esto de otra maneras: de la gloria de la fe a la gloria de la visión; de la gloria con la cual somos hijos de Dios, a la gloria con la que seremos semejantes a Él, porque le veremos tal cual es (I Joh 3, 2)"66.

Finalmente, nos queda resaltar cómo esta transformación progresiva, que puede darse solo con el concurso de nuestra voluntad, solo puede realizarse porque nuestra voluntad es en esencia imagen de la eterna Voluntad, es decir del Amor Primero, el Espíritu Santo: "He indicado que, en este enigma [=imagen oscura] no hay nada que se muestre semejante al Espíritu Santo, sino nuestra voluntad, o amor, o dilección, que es una voluntad más intensa" ${ }^{37}$.

Pero ella solo puede cumplir esta esencia de imagen, o sea puede volverse imagen luminosa, si deja que el Espíritu mismo se una a ella, cosa que Agustín expresa con la metáfora bíblica de la inhabitación, junto con otras imágenes ${ }^{68}$. Solo el Espíritu puede hacer que se encienda en nosotros el amor a $\operatorname{Dios}^{69}$; y junto con él, también el verdadero amor del prójimo: el amor gratuito, más allá de la mera cupiditas.

${ }^{65}$ Trin. XV, viii, 14, 24-26: "Transformamur ergo dicit, de forma in formam mutamur, atque transimus de forma obscura in formam lucidam.

66 Trin. XV, viii, 14, 34-39.

67 Trin. XV, xxi, 41, 1-3: "De Spiritu autem Sancto nihil in hoc aenigmate quod ei simile videretur ostendi, nisi voluntatem nostram, vel amorem seu dilectionem quae valentior est voluntas".

68 Sobre todo las imágenes relacionadas con el agua viva, cf. Trin. XV, xix, 33, 23-29.

69 Trin. XV, xvii, 31, 127-131: "Deus igitur Spiritus Sanctus qui procedit ex Deo, cum datus fuerit homini, accendit eum in dilectionem Dei et proximi, et ipse $D i$ lectio est. Non enim habet homo unde Deum diligat, nisi ex Deo". 
Así como el verbo con que el alma se conoce es verdadero verbo si coincide con aquel que es pronunciado en el Verbo -es decir, con aquello que el Verbo conoce y dice que el alma es y está llamada a ser-, del mismo modo la voluntad con la que el hombre ama es verdadero amor cuando coincide, y por tanto se une o mejor dicho, se deja unir al Amor Verdadero y a aquello que el Amor quiere que el alma llegue a querer.

"Por lo tanto, el amor que es de Dios, y es Dios, es propiamente el Espíritu Santo, por el cual se difunde en nuestros corazones el amor de Dios, mediante el cual habita en nosotros toda la Trinidad"70.

La inhabitación de la Trinidad en el hombre es, por consiguiente, el verdadero fin del hombre.

Es por ello, paradójicamente, que conocerse a sí mismo de verdad es, en realidad, conocer principalmente a Otro. Pues conocernos como realmente somos es conocernos como espejos. Quien se mira a sí mismo, sin darse cuenta de que es primariamente un espejo, no se conoce realmente por lo que es, pues no mira la imagen que por esencia en él se refleja. Es por eso, subraya Agustín, que el Apóstol no dice: "vemos un espejo", sino "vemos por un espejo":

"Por eso, los que ven su propia mente, del modo en que puede ser vista, y en ella ven esta trinidad, de la cual he discutido de muchas manera según mis posibilidades, y sin embargo no creen, ni entienden, que ella es imagen de Dios, ven sí el espejo, pero hasta tal punto no ven por el espejo a Aquel a quien ahora hay que ver por el espejo, que, del mismo espejo, ni saben que es un espejo, es decir, una imagen. Si lo supieran, quizás se darían cuenta que por medio de él hay que amar, y por medio de él hay que ver, de algún modo, en la espera, a Aquel del cual es espejo" ${ }^{\prime 1}$.

\section{REFLEXIONES CONCLUSIVAS}

La famosa sentencia de Jesús, según la cual hay que negarse a sí mis$\mathrm{mo}^{72}$, a primera vista contradice diametralmente el dicho del oráculo délfico, según el cual hay que conocerse a sí mismo.

Trin. XV, xviii, 32, 26-29.

71 Trin. XV, xxiii, 44, 54-56. XV, xxiv, 44, 1-6.

72 Cf. Mat 16, 24. 
También el análisis de Agustín, que tanto insiste sobre la importancia metafísica y gnoseológica de la memoria sui, puede parecer a primera vista no tomar en cuenta, en este aspecto, la enseñanza del Maestro. Sin embargo, bien mirado, el largo itinerario agustiniano del De Trinitate muestra de un modo extraordinariamente profundo la esencial verdad metafísica de la sentencia de Jesús: es precisamente el conocerse a sí mismo lo que permite negarse a sí mismo, pues permite tomar gradualmente conciencia de la Presencia Divina, lo único que realmente puede desplazar el pequeño, pero ambicioso, yo humano del centro de la propia atención, para colocarlo en su verdadera perspectiva y proporción, en humilde armonía con la Realidad verdadera de Dios y del prójimo.

En conclusión: por un lado, como hemos tenido ocasión de apreciar, Agustín se coloca en un filón especialmente fecundo de la filosofía helénica, el tema del "conócete a sí mismo"; por otro, mediante un análisis riguroso, estrictamente racional e iluminado al mismo tiempo por los textos de la Revelación, Agustín profundiza el mensaje cristiano, neutralizando eficazmente los principales riesgos en que caía la sistematización neoplatónica: en esta, el alma que, conociéndose a sí misma, descubre ser parte del Alma universal, directamente generada de la suprema Inteligencia, difícilmente puede evitar el riesgo de auto-divinizarse. En el itinerario plotiniano, como hemos visto, el alma pasa, por así decir, del complejo de baja autoestima que le deriva del afanarse detrás de los bienes materiales, a la exaltación exagerada que es necesaria consecuencia de su auto-identificación con la Inteligencia y el Uno. Paradójicamente, este exceso de autoestima lleva a una consecuencia inesperada: la virtual anulación del mismo ser humano como ser distinto de la Divinidad, con un valor y un fin en sí mismo. El hombre pasa a ser nada más que un momento accidental del desarrollo de la Divinidad que, después de la necesaria procesión del Uno, vuelve al Uno con una conversión igualmente necesaria.

De este modo, la búsqueda de la justa relación entre el hombre y Dios, implícitamente contenida en el mensaje del antiguo dicho délfico, que Platón se había esforzado en profundizar, es resuelta, en el ocaso de la meditación helénica, con la anulación, al menos virtual, de uno de los términos de la relación misma, el hombre como tal ${ }^{73}$. Decimos virtual, por cuanto la anulación de la esencia humana no es, ni mucho menos,

73 Cf Plotino, Enéada V, 3, 4, 3-12 (cf. supra, nota 23). 
directamente afirmada por Plotino; pero sí está potencialmente contenida en las líneas portantes de su sistema. El sistema plotiniano no es todavía, ciertamente, un sistema de la identidad absoluta: pero hay poca duda de que es dentro de su tradición y sobre sus presupuestos que se fundarán tales sistemas en los siglos sucesivos, alcanzando sus expresiones más acabadas en la época moderna ${ }^{74}$.

Con Agustín, en el complejo desarrollo de su obra maestra teológica y antropológica, aun inspirándose en elementos clave de la filosofía platónica, la filosofía cristiana fortalece y fundamenta de manera decisiva su camino en una dirección radicalmente diferente de esta, al subrayar tres elementos sobre todo:

1) El proceso de autoconocimiento lleva al hombre a descubrir su carácter de imagen de la Trinidad como un don, puramente libre, voluntario y gratuito de parte del Amor divino, en ningún caso un desarrollo necesario de la divina esencia. La naturaleza humana, para existir como tal, necesita ser un espejo, que refleja la imagen de la Trinidad; la Trinidad, por su parte, es el Ser absoluto, que subsiste en la plena y eterna realidad de sus relaciones intra-divinas.

2) Por lo anterior, la trinidad humana, que constituye la esencia del hombre, y que el hombre descubre en su profundidad, no se identifica con la Trinidad divina, siendo una esencia creada y no generada, radicalmente dependiente e infinitamente distante de su Creador.

3) Finalmente: fruto del proceso de autoconocimiento, y al mismo tiempo parte de este proceso es la respuesta humana a la llamada divina a cumplir esta semejanza, con un acto también libre y voluntario, no necesario, de asimilación a la voluntad divina mediante la acogida del Amor gratuito.

En suma: ambos maestros dan un aporte clave a la profundización de una verdad fundamental, a saber, que el autoconocerse del hombre en

74 Sobre el influjo del neoplatonismo en el idealismo alemán, véase p.ej. el penetrante estudio de Werner Beierwaltes, Platonismus und Idealismus (Vittorio Klostermann, Frankfurt am Main 1972). Cuando la Iglesia Católica, en el siglo XIX, se verá en la obligación de dar una respuesta frente a las poderosas corrientes del pensamiento idealista, podrá hacerlo precisamente sintetizando estos fundamentos de la Teología natural, ya tan claramente delineados por Agustín (cf. Concilio Vaticano I, Dei Filius, 1, DH3001-3003; Cánones 1-5, DH3021-3025). 
sus relaciones intra-psíquicas equivale a conocerse fundamentalmente en sus relaciones con la Divinidad.

Sin embargo, en Plotino, el acto del autoconocimiento humano termina identificándose con el acto del autoconocimiento divino, no pudiéndose, a la larga, evitar el riesgo de una virtual disolución de la esencia humana. En Agustín, en cambio, el acto del autoconocimiento humano coincide con el progresivo acto de libre realización de la perfecta semejanza del hombre con Dios por la unión con la esencia divina; no por la fusión de la naturaleza humana con la naturaleza divina, sino por la eterna unión amorosa entre las dos: desde el esse in Deo, hasta el esse cum Deo. 